\title{
Regulation of the heat shock transcriptional response: cross talk between a family of heat shock factors, molecular chaperones, and negative regulators
}

\author{
Richard I. Morimoto ${ }^{1}$ \\ Department of Biochemistry, Molecular Biology, and Cell Biology, Rice Institute for Biomedical Research, Northwestern \\ University, Evanston, Illinois 60208 USA
}

Our cells and tissues are challenged constantly by exposure to extreme conditions that cause acute and chronic stress. Consequently, survival has necessitated the evolution of stress response networks to detect, monitor, and respond to environmental changes (Morimoto et al. 1990, 1994a; Baeuerle 1995; Baeuerle and Baltimore 1996; Feige et al. 1996; Morimoto and Santoro 1998). Prolonged exposure to stress interferes with efficient operations of the cell, with negative consequences on the biochemical properties of proteins that, under ideal conditions, exist in thermodynamically stable states. In stressed environments, proteins can unfold, misfold, or aggregate. Therefore, the changing demands on the quality control of protein biogenesis, challenges protein homeostasis, for which the heat shock response, through the elevated synthesis of molecular chaperones and proteases, repairs protein damage and assists in the recovery of the cell.

The inducible transcription of heat shock genes is the response to a plethora of stress signals (Lis and Wu 1993; Morimoto 1993; Wu 1995) (Fig. 1), including (1) environmental stresses, (2) nonstress conditions, and (3) pathophysiology and disease states. Although changes in heat shock protein (HSP) expression are associated with certain diseases (Morimoto et al. 1990), these observations leave open the question of whether this is an adaptation to the particular pathophysiological state, a reflection of the suboptimal cellular environment associated with the disease, or serves to warn other cells and tissues of imminent danger.

The protective role of HSPs is a measure of their capacity to assist in the repair of protein damage. Whether in prokaryotes, plants, or animals, overexpression of one or more HSPs is often sufficient to protect cells and tissues against otherwise lethal exposures to diverse envi-

${ }^{1}$ Corresponding author.

E-MAIL r-morimoto@nwu.edu; FAX (847) 491-4461. ronmental stresses including hydrogen peroxide and other oxidants, toxic chemicals, extreme temperatures, and ethanol-induced toxicity (Parsell and Lindquist 1994). In vertebrate tissue culture cells and animal models, elevating HSPs level, either by modulation of the heat shock response or by constitutive overexpression of specific heat shock proteins, restricts or substantially reduces the level of pathology and cell death (Mizzen and Welch 1988; Huot et al. 1991; Jaattela et al. 1992; Parsell and Lindquist 1994; Mestril et al. 1994; Plumier et al. 1995; Marber et al. 1995; Mehlen et al. 1995; Mosser et al. 1997). This has led to the recognition that HSPs, via their chaperoning effects on proteins, protect cells from many forms of stress-induced cell damage and could influence the course of disease.

The heat shock factor family: redundancy and specialization

The stress signal that activates the heat shock response is widely held to be the flux of non-native, such as, nipfridid proteins (Morimoto et al. 1994b). Adaptation to this stress, in turn, leads to the elevated expression of heat shock genes such that molecular chaperones are rapidly synthesized and deployed to prevent protein misfolding and to assist in their refolding to the native state. Stress-induced transcription requires activation of heat shock factor (HSF) (Lis and Wu 1993; Morimoto 1993; Voellmy 1994, 1996; Wu 1995) that binds to the heat shock promoter element (HSE), characterized as multiple adjacent and inverse iterations of the pentanucleotide motif 5'-nGAAn-3' (Fernandes et al. 1994). An unexpected complexity of the regulation of the heat shock response was the finding that plants and larger animals, unlike yeast and Drosophila, have multiple HSFs (Sorger and Pelham 1988; Wiederrecht et al. 1988; Clos et al. 1990; Scharf et al. 1990, 1993; Sarge et al. 1991; Schuetz et al. 1991; Nakai and Morimoto 1993; Treuter et al. 


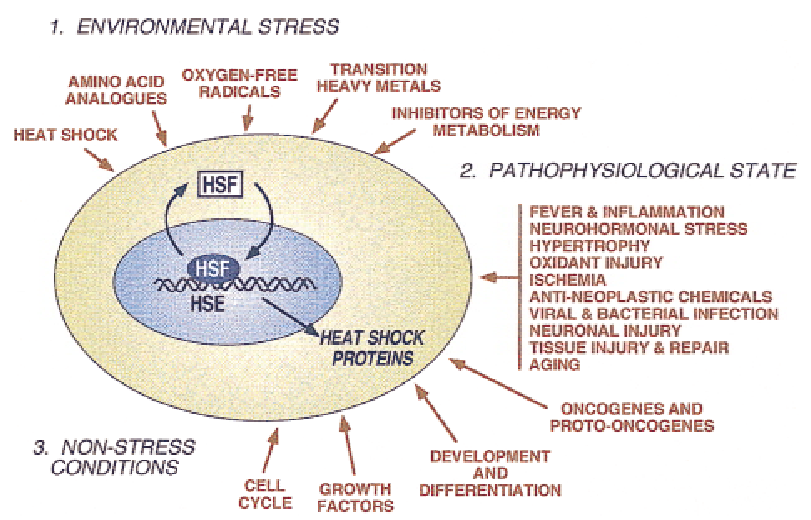

Figure 1. Conditions that induce the heat shock response. Heat shock gene expression represented here by the activation of HSF and binding to HSE results in the elevated expression of HSPs such as Hsp70. The regulatory conditions are represented by environmental and physiological stress and nonstressful conditions, including cell growth and development and pathophysiological states.

1993; Czarnecka-Verner et al. 1995; Nover et al. 1996; Nakai et al. 1997). Among vertebrates, HSFs 1, 2, and 4 are ubiquitous, whereas HSF3 has been characterized only in avian species (Table 1). Thus far, our understanding of the role and function of each of these HSFs is incomplete. However, it appears that the diversity of HSFs provides redundancy and specialization of stress signals, a means to differentially control the rate of transcription of heat shock genes, and provides novel inter- actions with other regulatory factors thus expanding the link between cell stress and other genetic networks.

Among the various cloned HSF genes, there is an overall sequence identity of $40 \%$ with structural conservation (Fig. 2) in the winged helix-turn-helix DNA binding domain (Harrison et al. 1994; Vuister et al. 1994; Schultheiss et al. 1996), an adjacent 80 residue hydrophobic repeat (HR-A/B) essential for trimer formation (Sorger and Nelson 1989; Clos et al. 1990; Peteranderl and Nelson 1992), and the carboxy-terminal transactivation domain (Chen et al. 1993; Green et al. 1995; Shi et al. 1995; Zuo et al. 1995; Wisniewski et al. 1996). With the exception of the HSF in budding yeast and human HSF4, another hydrophobic repeat (HR-C) is located adjacent to the transactivation domain; this repeat has been suggested to suppress trimer formation by interacting with HR-A/B (Nakai and Morimoto 1993; Rabindran et al. 1993). Also, positioned between HR-A/B and HR-C are sequences that negatively regulate DNA binding and transcriptional activation (Nieto-Sotelo et al. 1990; Hoj and Jakobsen 1994; Green et al. 1995; Shi et al. 1995; Zuo et al. 1995). Other features unique to certain HSFs are the presence of an amino-terminal transactivation domain in the Saccharomyces cerevisiae HSF (Sorger 1990) and spliced variants of mouse and human HSF2 and HSF4, which have variable transactivation properties (Fiorenza et al. 1995; Goodson et al. 1995; A. Nakai, pers. comm.). Apart from S. cerevisiae, the HSF form present in unstressed cells is a latent monomer that lacks both DNA binding and transcriptional activity (Larson et al. 1988; Clos et al. 1990; Rabindran et al. 1991; Sarge et al.

Table 1. Characterization of HSFs across species

\begin{tabular}{|c|c|c|c|c|}
\hline & HSF1 & HSF2 & HSF3 & $\mathrm{HSF}^{\mathrm{a}}$ \\
\hline Organisms & Human, mouse, chicken & human, mouse, chicken & chicken & human \\
\hline Homology & $92 \%$ between species & $92 \%$ between species & & \\
\hline Expression & ubiquitous & ubiquitous & ubiquitous & $\begin{array}{l}\text { tissue-specific } \\
\text { heart, skeletal } \\
\text { muscle, brain }\end{array}$ \\
\hline
\end{tabular}

\begin{tabular}{|c|c|c|c|c|c|c|c|c|}
\hline $\begin{array}{l}\text { In vivo } \\
\text { conditions }\end{array}$ & $37^{\circ} \mathrm{C}$ & $42^{\circ} \mathrm{C}$ & $37^{\circ} \mathrm{C}$ & $42^{\circ} \mathrm{C}$ & $\begin{array}{l}\text { Hemin/ } \\
\text { MG-132 }\end{array}$ & $37^{\circ} \mathrm{C}$ & $45^{\circ} \mathrm{C}$ & $37^{\circ} \mathrm{C}^{\mathrm{c}}$ \\
\hline \multicolumn{9}{|l|}{ Protein size } \\
\hline native (kD) & 70 & 178 & 127 & 127 & 202 & & & \\
\hline denatured (kD) & 70 & 85 & 72 & 72 & 72 & 69 & 69 & 55 \\
\hline $\begin{array}{l}\text { Subcellular } \\
\text { localization }\end{array}$ & $\mathrm{C} / \mathrm{N}$ & $\mathrm{N}$ & $\mathrm{C}$ and $\mathrm{N}$ & $\mathrm{C}$ and $\mathrm{N}$ & $\mathrm{N}$ & $\mathrm{C}$ & $\mathrm{N}$ & $\begin{array}{l}\text { constitutively } \\
\text { nuclear }\end{array}$ \\
\hline Oligomeric state & M & $\mathrm{T}$ & $\mathrm{D}$ & $\mathrm{D}$ & $\mathrm{T}$ & $\mathrm{D}$ & $\mathrm{D}$ & $\mathrm{T}$ \\
\hline DNA binding & & + & - & - & + & - & + & $\begin{array}{l}\text { constitutive DNA } \\
\text { binding but lacks } \\
\text { transcriptional } \\
\text { activity }\end{array}$ \\
\hline $\begin{array}{l}\text { Biochemical } \\
\text { modifications }\end{array}$ & $\begin{array}{l}\text { constitutive } \\
\text { phosphorylation }\end{array}$ & $\begin{array}{l}\text { inducible } \\
\text { phosphorylation }\end{array}$ & - & - & - & - & - & - \\
\hline
\end{tabular}

(C) Cytoplasmic; (N) nuclear; (M) monomer; (D) dimer; (T) trimer.

${ }^{a}$ Analysis based on transient or stably transfected cells.

${ }^{b}$ Hemin, an iron-containing protein, is an inducer of erythroid differentiation in human K562 cells. MG-132 is a peptide aldehyde inhibitor of the ubiquitin-dependent proteasome.

${ }^{\mathrm{c}}$ DNA-binding activity is lost in vitro upon heat shock. 

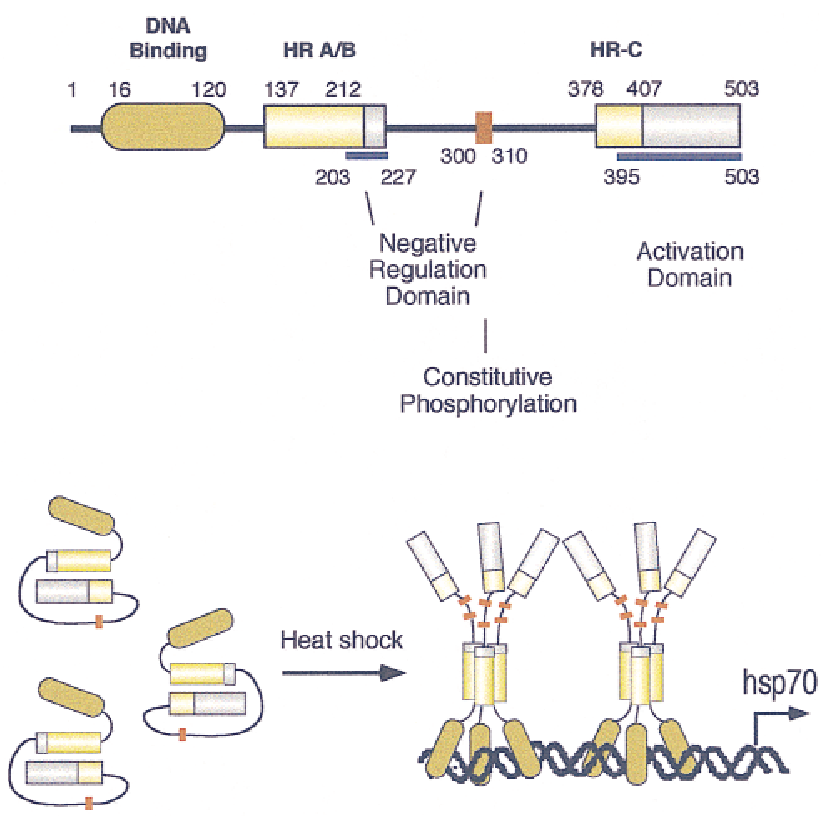

Figure 2. General structural and regulatory features of HSFs. Schematic representation of HSF1 structural motifs corresponding to the DNA-binding domain, hydrophobic heptad repeats (HR-A/B and HR-C), the carboxy-terminal transcriptional activation domain, and the negative regulatory domains that influence HSF1 activity. The relative positions of these domains in HSF1 are indicated by the amino acid residues. Shown below is a schematic of the intramolecular negatively regulated monomer that, upon stress exposure, is activated to form homotrimers with DNA-binding activity.

1991, 1993; Baler et al. 1993; Westwood and Wu 1993; Zuo et al. 1994).

Of the HSFs coexpressed in vertebrates, HSF1 is functionally analogous to yeast and Drosophila HSF as the principal stress-induced transcription factor (Nakai et al. 1993; Rabindran et al. 1991; Sarge et al. 1991). Yeast HSF is essential and in Drosophila, loss of HSF exhibits an early developmental phenotype and is essential for induction of the heat shock response and stress tolerance (Wiederrecht et al. 1988; Jedlicka et al. 1997; Sorger et al. 1988). Mice lacking HSF1 can develop normally and attain adulthood. However, fibroblasts derived from HSF1deficient mice are incapable of stress-induced transcription of heat shock genes, consistent with the expectations of the central role of HSF1 in the heat shock response (McMillan et al. 1998).

Activation of HSF1 (see below) is in response to a multitude of stress conditions, such as heat shock, oxidative stress, and amino acid analogs that lead to the synthesis of non-native proteins (Morimoto et al. 1990, 1994b, 1996; Wu 1995). Because heat shock also leads to the inhibition of protein synthesis, and in doing so prevents the appearance of nascent polypeptides that could misfold, HSF1 has an important role in the molecular response to non-native proteins. In the stressed cell, the fate of non-native proteins therefore depends exquisitely upon molecular chaperones to capture and maintain in- termediate folded states, and upon recovery to facilitate their refolding or degradation. In avian cells, HSF1 and HSF3 are coexpressed and coactivated by chemical and physiological stress, which led to the suggestion of HSF regulatory and function redundancy (Nakai et al. 1995; Tanabe et al. 1997). However, it is now clear that cells lacking HSF3 are severely compromised for induction of the heat shock response even though HSF1 is expressed (Tanabe et al. 1998). HSF3 also interacts with other transcription factors and can be activated by the Myb oncogene, independent of stress, via direct protein-protein interaction between the HSF3 and Myb DNA binding domains (Kanei-Ishii et al. 1997). The interactions between Myb and HSF3 reveal novel genetic regulatory pathways that connect events of cell growth and cell stress.

Relative to the more complete characterization of HSF1 during the heat shock response, the regulation and role of HSF2 has been an enigma. Induction of the DNA binding properties of HSF2 is accompanied by a transition from an inert dimeric state to an activated trimer and occurs during early mouse embryonic development, spermatogenesis, and in human erythroleukemia K562 cells exposed to hemin (Theodorakis et al. 1989; Sistonen et al. 1992; 1994; Mezger et al. 1994; Sarge et al. 1994; Rallu et al. 1997). Although these results suggested that HSF2 activity was associated with development and differentiation, the events responsible for activation of HSF2 were uncharacterized. The stress signal responsible for HSF2 activation was recently shown to result from downregulation of the ubiquitin-dependent protein degradation machinery (Mathew and Morimoto 1998). Incubation of mammalian cells expressing HSF2 with specific inhibitors of the ubiquitin-proteasome pathway, such as MG132 or lactacystin, resulted in the activation of HSF2 DNA binding activity in a cell-type-independent mechanism. Unlike HSF1, HSF2 is a labile protein whose concentration increases upon inhibition of proteasome activity (Mathew et al. 1998). These results establish a role for HSF2 in the heat shock response as a molecular response to the flux of non-native proteins targeted for protein degradation, as a complement to HSF1 that is principally activated by the flux of newly synthesized non-native proteins. Consequently, the kinetics of HSF1 activation typically is very rapidly relative to the delayed activation profile of HSF2 (Sistonen et al. 1994). Selex experiments performed to identify the optimal nucleotide binding sites for HSF1 and HSF2 have suggested potential distinctions in preferences for the consensus HSE and differences in the numbers of HSE pentamer binding sites required for optimal binding of either HSF (Kroeger and Morimoto 1994). These studies have raised the possibility that HSF2 may have distinct target genes from those of HSF1, as well as differing specificities for common target genes (Leppa et al. 1997; Liu et al. 1997).

General features of heat shock gene transcription following binding of HSF to its target have been elucidated elegantly and will only be summarized here briefly as this has been the topic of recent reviews (Lis and Wu 
1993; Wu 1995). The inducible binding of HSF leads to changes in the organization of chromatin structure localized to the 5 -flanking regions of heat shock genes (Wu 1980, 1984; Giardina et al. 1992). Although HSF associates with components of the chromatin remodeling machinery (Becker and $\mathrm{Wu}$ 1992; Tsukiyama et al. 1994; Brown and Kingston 1997) and the basal transcriptional machinery, association specifically with TBP also has been detected (Mason and Lis 1997). Such interactions may be critical for the release of the paused RNA polymerase II that represents a pre-initiated nascent transcript that elongates in a stress-dependent manner to yield inducible heat shock mRNAs (Gilmour and Lis 1986; Rougvie and Lis 1988).

\section{Who detects stress?}

Does HSF directly sense its biochemical environment? Although heat shock has been the typical stress condition employed, HSF trimer formation cannot solely be a temperature-regulated event because the majority of stressors have their effect in cells grown at $37^{\circ} \mathrm{C}$. Yet, there exists a substantial amount of data indicating that HSF translated in vitro in reticulocyte lysates can be activated by heat shock and that purified Drosophila HSF or recombinant mouse and human HSF1 can acquire DNA binding upon in vitro heat shock (Mosser et al. 1990; Goodson and Sarge 1995; Larson et al. 1995; Zhong et al. 1998). Likewise, in vitro translated HSF1 or purified HSF can be activated by low $\mathrm{pH}(\mathrm{pH}$ 6.5) or salicylate (Mosser et al. 1990; Zhong et al. 1998). As salicylate is an organic acid, its effect on HSF activity could be analogous to the activating effects of low $\mathrm{pH}$, perhaps acting on HSF1 conformation. Although these results suggest that the intrinsic properties of HSF can be modulated by its biochemical environment, they do not exclude a role for other negative regulators that may function to keep HSF in the repressed state.

Is activation of HSF1 a titrated phenomenon such that simultaneous or subsequent exposure to multiple stressors at subthreshold levels leads to a complete heat shock response? This issue addresses whether stress has multiple distinct targets or stress receptors and whether these stress signals converge upon common pathways. The temperature for activation of HSF is not an absolute; to illustrate this point, growing HeLa cells at temperatures $<37^{\circ} \mathrm{C}$ reduces the temperature required for complete activation of HSF1 (Abravaya et al. 1991). Likewise, human HSF1 expressed in Drosophila cells becomes activated at the temperature of the Drosophila heat shock response $\left(37^{\circ} \mathrm{C}\right)$ (Clos et al. 1993). Consistent with these observations, incubation of mammalian cells with a subthreshold concentration (for HSF1 activation) of indomethacin or other nonsteroidal anti-inflammatory drugs sensitizes treated cells such that the temperature or stress required for induction of the heat shock response is reduced (Lee et al. 1995). These observations support the notion that many if not all of the inducers of the heat shock response converge on common pathways resulting from an imbalance in protein homeostasis.

\section{HSF cycle: feedback from molecular chaperones and negative regulators}

Under normal growth conditions in metazoans, HSF1 activity is repressed and exists either in the cytosol or nucleus in an inert monomeric state. Negative regulation of the DNA binding and transactivation domains involves intramolecular interactions with the central region of HSF1 and is also influenced by constitutive phosphorylation at critical serine residues (Knauf et al. 1996; Kline and Morimoto 1997). Molecular chaperones such as Hsp90 have also been shown to have a role in maintaining HSF1 in an inert state (Ali et al. 1998; Zuo et al. 1998). However it remains to be demonstrated how interactions with specific chaperones maintains the repressed monomeric state or shifts the equilibrium back to the monomer. Heat shock and other stresses cause derepression of HSF1, initiating the events that lead to the appearance of the transcriptionally active trimer. Activation of HSF1 is a multistep process (Fig. 3) that results in a transcriptionally competent state that is characterized typically by hyperphosphorylation at multiple serine residues (Hensold et al. 1990; Jurivich et al. 1992; Sarge et al. 1993; Cotto et al. 1996; Kline and Morimoto 1997). Although heat shock and most other stresses convert HSF1 to the fully active trimer, sodium salicylate treatment activates HSF1 to an intermediate trimeric state, which is bound in vivo to the promoter of the Hsp70 gene, yet is transcriptionally inert (Jurivich et al. 1992). It is intriguing to note that the two DNA binding competent forms of metazoan HSF that differ in transcriptional activity correspond respectively to the control and activated forms of S. cerevisiae HSF (Sorger et al. 1987). Thus, despite the ancient origins of the heat shock response, the regulation of HSF has, along the way, acquired additional levels of control.

If the function of the heat shock response is to increase the levels of heat shock proteins, then what mechanism exists to repress the response? A substantial amount of genetic and biochemical evidence from studies in prokaryotes and eukaryotes support a role for heat shock proteins in the negative regulation of heat shock. For example, in yeast, an extragenic suppressor of an Hsp70 mutant that exhibits a poor-growth phenotype at $37^{\circ} \mathrm{C}$ was identified as a mutant allele of HSF that had reduced DNA binding activity (Halladay and Craig 1995). Complexes of Hsp70 and HSF trimers have been detected during attenuation of the heat shock transcriptional response (Abravaya et al. 1992; Baler et al. 1992; Shi et al. 1998) and consistent with a regulatory role for chaperones in the heat shock response, overexpression of Hsp70 or Hdj-1/Hsp40 in the absence of stress prevents the inducible transcription of heat shock genes (Mosser et al. 1993; Rabindran et al. 1994; Shi et al. 1998). Although the mechanism by which Hsp70 and Hdj1/Hsp40 repress HSF1 has not been fully elucidated, these molecular chaperones bind directly to the HSF1 transactivation domain (Fig. 3). The Hsp70 chaperones and cochaperones alone are insufficient to prevent the appearance of HSF1 trimers; these results demonstrate that the 
Figure 3. Regulation of the heat shock response and the HSF cycle. Activation of heat shock factor 1 (HSF1) is linked to the appearance of nonnative proteins and the requirement for molecular chaperones (Hsp90, Hsp70, and Hdj1) to prevent the appearance of misfolded proteins. HSF1 exists in the control state in the cytoplasm or nucleus as an inert monomer (shown as intramolecularly negatively regulated for DNA-binding and transcriptional activity) through transient interactions with chaperones such as Hsp90 and Hsp70. Activation of HSF1 is associated with a step-wise process, including relocalization to the nucleus and acquisition of a DNA binding competent state that is transcriptionally inert, stressinducible phosphorylation associated with transcriptional activity, and inducible transcription of heat shock genes. During attenuation of the heat shock response, the transcriptional activity of HSF1 is repressed by direct binding of Hsp70 and $\mathrm{Hdj}-1$, and the trimers are negatively regulated by HSF binding protein 1 (HSBP1), which binds both to the hydrophobic heptad repeat of HSF1 and to Hsp70. These events lead to the dissociation of HSF1 trimers and appearance of HSF1 inert monomers.

acquisition of transcriptional activity is a distinct process from regulation of trimer formation.

Given the ease by which HSF1 is activated, perhaps it would not be surprising were the cell to expend additional efforts to monitor and control the activated state of HSF. For example, the stable conversion of the trimer to monomer might be expected to involve additional steps, including dissociation of the trimers by destabilization of the hydrophobic heptads, dephosphorylation, and refolding to the inert monomeric state. Using a yeast two-hybrid protein interaction screen, a novel protein that associates specifically with the HSF hydrophobic heptads and regulates its activity was identified (Satyal et al. 1998). Heat shock factor binding protein 1 (HSBP1), is a conserved protein (from Caenorhabditis elegans to humans) of 76 amino acids that contains an extended hydrophobic heptad repeat that is necessary for interaction with the hydrophobic heptads of HSF1. HSBP1 interacts both with the trimeric state of HSF1 and Hsp70, and not with the monomeric form of HSF1 (Fig. 3). HSBP1 has the properties of a negative regulator of the heat shock response. Overexpression of the C. elegans HSB-1 (CeHSB-1) in a tissue-specific manner inhibited the heat shock response in transgenic animals containing an integrated heat shock reporter construct (Fig. 4). The phenotypes that result from increased or decreased levels of CeHSB-1 offer intriguing hints into the complexity of the heat shock response. CeHSB-1 overexpression reduces animal survival following extreme thermal and chemical stress, whereas loss of CeHSB-1 expression increases stress survival above that of wild-type animals. Thus, although CeHSB-1 may have an important role in the regulation of HSF activity and the heat shock transcriptional response, other redundant mechanisms ensure survival.

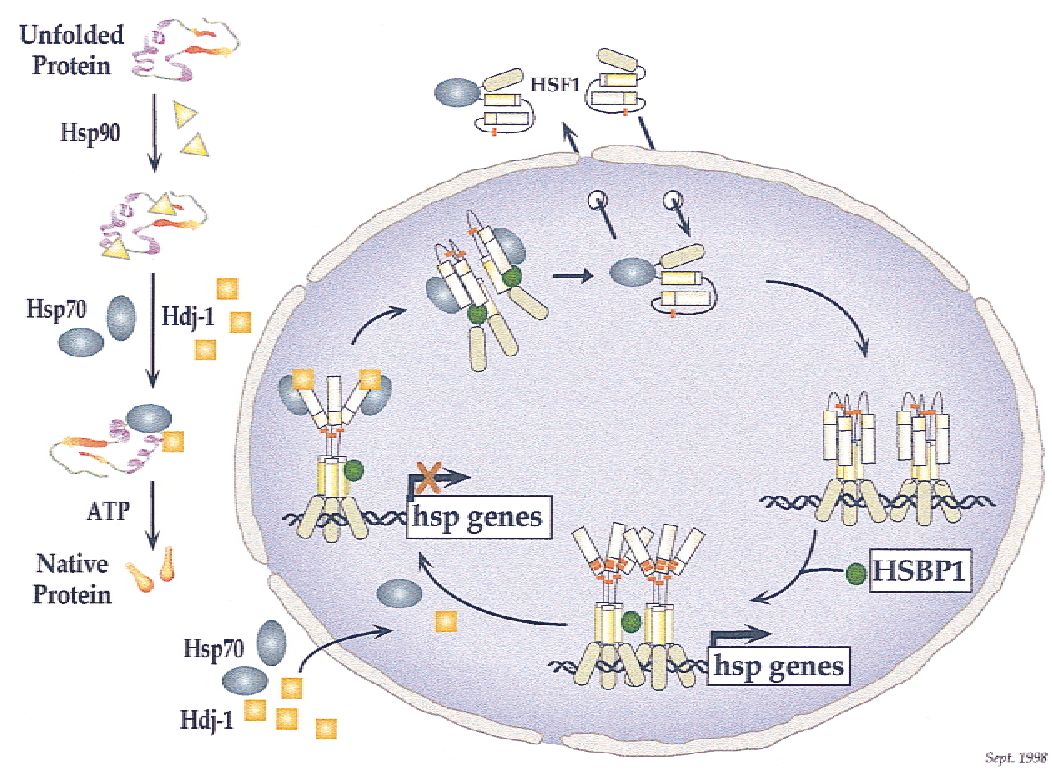

Numerous questions remain regarding the roles of molecular chaperones and HSBP1 in regulating the heat shock response. Rather than function stoichiometrically with HSF1, HSBP1 and the molecular chaperones may function catalytically to associate transiently with and destabilize the HSF1 hydrophobic heptads, thus allowing chaperones and other yet unidentified molecules to shift the equilibrium of HSF1 trimers to the monomer. Although these proteins function as negative regulators of HSF1 activity, features of how and when they bind, and
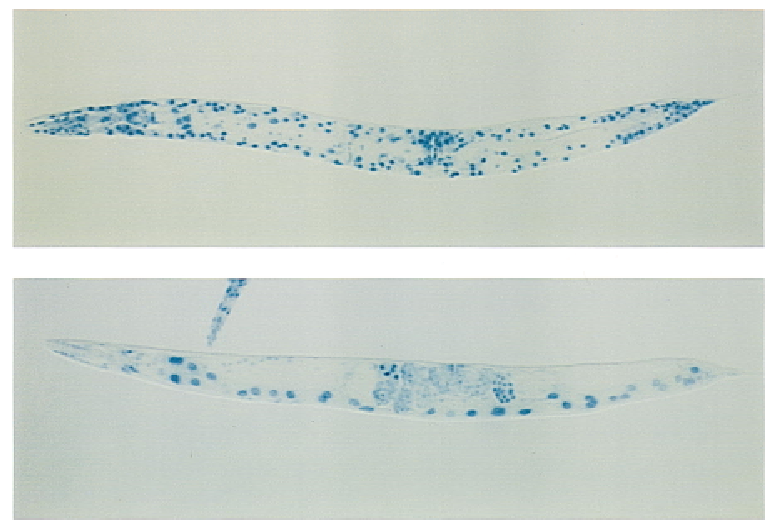

Figure 4. Overexpression of CeHSB-1 results in a block in activation of the stress response in C. elegans. (Top) Animals containing integrated copies of the hsp16:1acZ gene fusion heatshocked at $33^{\circ} \mathrm{C}$ and stained for $\beta$-galactosidase activity. The heat shock response is detected by $\beta$-gal staining in responsive cells. (Bottom) Animals containing both the hsp16:1acZ fusion and integrated copies of an unc-54:hsb-1 gene fusion exposed to heat shock. Note that the Hsp16:LacZ fusion protein is not expressed upon heat shock in body wall muscle cells where the unc-54 promoter is expressed. (From Satyal et al. 1998.) 
the consequence of forming a macromolecular complex with HSF1 remain to be understood.

\section{Organizing the stress response: stress-induced intranuclear HSF granules}

Coincident with the stress-induced activation of HSF and the induction of heat shock gene transcription, HSF1 relocalizes within the nucleus to form unique, large irregularly shaped granules distinct from other nuclear bodies (Sarge et al. 1993; Cotto et al. 1997; Jolly et al. 1997). HSF1 granules (Fig. 5) have been detected in fixed human primary and transformed tissue culture cell lines by indirect immunofluorescence and in living human cells using a chimeric fusion between HSF1 and green fluorescent protein. The number of HSF1 foci detected in primary and transformed human cells correlates with the ploidy of the cells, consistent with HSF1 granules having a chromosomal target. HSF1 granules appear rapidly and transiently upon heat shock and other stresses, parallel with the activation and attenuation of HSF1 and the transcription of heat shock genes (Cotto et al. 1997). During attenuation, HSF1 granules are not detected and HSF1 redistributes to the general diffuse nuclear or cytoplasmic localization in unstressed cells. The appearance of HSF1 granules is strictly linked with transcriptional activation of heat shock genes as inducers, such as sodium salicylate which activate transcriptionally inert nuclear-localized HSF trimers, do not cause relocalization of HSF1 into HSF1 granules.

Although these results implicate a role for HSF1 granules as the sites of heat shock gene transcription, experiments using fluorescence in situ hybridization (FISH) analysis to map sites of Hsp90 $\alpha$ and Hsp90 $\beta$ and Hsp70 transcription, together with anti-HSF1 immunofluorescence, do not support this conclusion (Jolly et al. 1997). The association with heat shock gene transcription yet the absence of colocalization with HSF1 granules leaves open the intriguing possibility that HSF1 trimers shuttle between the DNA bound state and a compartmentalized state to coordinate the transcription of heat shock genes that are dispersed throughout the nucleus as another point where HSF1 activity is regulated.

\section{Prospectus}

Studies on the heat shock transcriptional response have

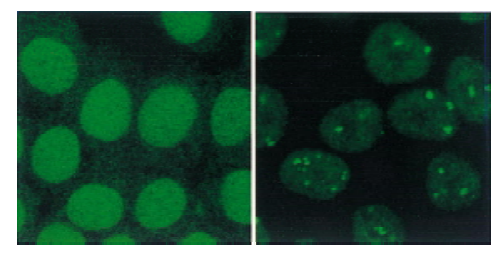

Figure 5. Heat shock causes relocalization of HSF1 to form HSF1 granules. Subcellular localization of HSF1 in human tissue culture cells either at control $\left(37^{\circ} \mathrm{C}\right.$; left $) 42^{\circ} \mathrm{C}(1 \mathrm{hr}$; right $)$ heat shock were analyzed by immunofluorescence using an anti-HSF1 rat monoclonal antibody $10 \mathrm{H} 8$. served many purposes, as a paradigm to assess the molecular response to stress, as a powerful tool to elucidate features of DNA structure, chromatin organization, and regulatory mechanisms associated with gene expression in the uninduced and induced state, and to decipher the molecular strategies employed by the cell to protect itself from deleterious consequences of transient and prolonged stress. Whether HSF is activated or repressed, therefore, reflects the equilibrium between negative regulators that in many cases provide a molecular buffer to non-native proteins and the effects of diverse forms of stress that cause a flux in non-native proteins. Future studies will establish how different members of the HSF gene family either respond to different forms of stress, ensure regulation at distinct stages of activation or repression of the heat shock response, or provide an interface between the stress response and other transcription regulatory pathways. Ultimately, these studies will lead to new insights on the integration of genetic regulatory switches and the role of molecular chaperones in cell growth, development, and cell death as the organism adjusts to the needs of development, adaptation, and survival.

\section{Acknowledgements}

I thank members of my laboratory, present and past, and colleagues worldwide who have contributed graciously to the work described in this review. In particular, I thank Sue Fox, Anu Mathew, Yanhong Shi, and Li Tai for their comments and assistance in completion of this manuscript, and Caroline Jolly for Figure 5. R.M. is supported by the National Institutes for General Medical Sciences.

\section{References}

Abravaya, K., B. Phillips, and R.I. Morimoto. 1991. Attenuation of the heat shock response in HeLa cells is mediated by the release of bound heat shock transcription factor and is modulated by changes in growth and in heat shock temperatures. Genes \& Dev. 5: 2117-2127.

Abravaya, K., M.P. Myers, S.P. Murphy, and R.I. Morimoto. 1992. The human heat shock protein hsp70 interacts with HSF, the transcription factor that regulates heat shock gene expression. Genes \& Dev. 6: 1153-1164.

Ali A., S. Bharadwaj, R. O'Carroll, and N. Ovsenek. 1998. HSP90 interacts with and regulates the activity of heat shock factor 1 in Xenopus oocytes. Mol. Cell. Biol. 18: 49494960.

Baeuerle, P.A. 1995. Inducible gene expression. Vol. I. Environmental stresses and nutrients. Vol. II. Hormonal signals. Birkhauser, Boston, MA.

Baeuerle, P.A. and D. Baltimore. 1996. NF-kappa B: ten years after. Cell 87: 13-20.

Baler, R., W.J. Welch, and R. Voellmy. 1992. Heat shock gene regulation by nascent polypeptides and denatured proteins: hsp70 as a potential autoregulatory factor. J. Cell Biol. 117: 1151-1159.

Baler, R., G. Dahl, and R. Voellmy. 1993. Activation of human heat shock genes is accompanied by oligomerization, modification, and rapid translocation of heat shock transcription factor HSF1. Mol. Cell. Biol. 13: 2486-2496. 
Becker, P.B. and C. Wu. 1992. Cell-free system for assembly of transcriptionally repressed chromatin from Drosophila embryos. Mol. Cell. Biol. 12: 2241-2249.

Brown, S.A. and R.E. Kingston. 1997. Disruption of downstream chromatin directed by a transcriptional activator. Genes \& Dev. 11: 3116-3121.

Chen, Y., N.A. Barlev, O. Westergaard, and B.K. Jakobsen. 1993. Identification of the C-terminal activator domain in yeast heat shock factor: Independent control of transient and sustained transcriptional activity. EMBO J. 12: 5007-5018.

Clos, J., J.T. Westwood, P.B. Becker, S. Wilson, K. Lambert, and C. Wu. 1990. Molecular cloning and expression of a hexameric Drosophila heat shock factor subject to negative regulation. Cell 63: 1085-1097.

Clos, J., S. Rabindran, J. Wisniewski, and C. Wu. 1993. Induction temperature of human heat shock factor is reprogrammed in a Drosophila cell environment. Nature 364: 252-255.

Cotto, J.J., M. Kline, and R.I. Morimoto. 1996. Activation of heat shock factor 1 DNA binding precedes stress-induced serine phosphorylation. Evidence for a multistep pathway of regulation. J. Biol. Chem. 271: 3355-3358.

Cotto, J., S. Fox, and R.I. Morimoto. 1997. HSF1 granules: A novel stress-induced nuclear compartment of human cells. J. Cell Sci. 110: 2925-2934.

Czarnecka-Verner, E., C.X. Yuan, P.C. Foxand, and W.B. Gurley. 1995. Isolation and characterization of six heat shock transcription factor cDNA clones from soybean. Plant Mol. Biol. 29: 37-51.

Feige, U. and W. van Eden. 1996. Infection, autoimmunity and autoimmune disease. Stress Inducible Cellular Responses 77: 359-373.

Fernandes, M., T. O'Brien, and J.T. Lis. 1994. Structure and regulation of heat shock gene promoters. In The biology of heat shock proteins and molecular chaperones (ed. R.I. Morimoto, A. Tissieres, and C. Georgopolis), pp. 375-393. Cold Spring Harbor Laboratory Press, Cold Spring Harbor, NY.

Fiorenza, M.T., T. Farkas, M. Dissing, D. Kolding, and V. Zimarino. 1995. Complex expression of murine heat shock transcription factors. Nucleic Acids Res. 23: 467-474.

Giardina, C., M. Perez-Riba, and J.T. Lis. 1992. Promoter melting and TFIID complexes on Drosophila genes in vivo. Genes \& Dev. 6: 2190-2200.

Gilmour, D.S. and J.T. Lis. 1986. RNA polymerase II interacts with the promoter region of the noninduced hsp70 gene in Drosophila melanogaster cells. Mol. Cell. Biol. 6: 39843989.

Goodson, M.L. and K.D. Sarge. 1995. Heat-inducible DNA binding of purified heat shock transcription factor 1. I. Biol. Chem. 270: 2447-2450.

Goodson, M.L., O.-K. Park-Sarge, and K.D. Sarge. 1995. Tissue dependent expression of heat shock factor 2 isoforms with distinct transcriptional activities. Mol. Cell. Biol. 15: 52885293.

Green, M., T.J. Schuetz, E.K. Sullivan, and R.E. Kingston. 1995. A heat shock-responsive domain of human HSF1 that regulates transcription activation domain function. Mol. Cell. Biol. 15: 3354-3362.

Halladay, J.T. and E.A. Craig. 1995. A heat shock transcription factor with reduced activity suppresses a yeast HSP70 mutant. Mol. Cell. Biol. 15: 4890-4897.

Harrison, C.J., A.A. Bohm, and H.C. Nelson. 1994. Crystal structure of the DNA binding domain of the heat shock transcription factor. Science 263: 224-227.

Hensold, J.O., C.R. Hunt, S.K. Calderwood, D.E. Housman, and R.E. Kingston. 1990. DNA binding of heat shock factor to the heat shock element is insufficient for transcriptional activation in murine erythroleukemia cells. Mol. Cell. Biol. 10: $1600-1608$.

Hoj, A. and B.K. Jakobsen. 1994. A short element required for turning off heat shock transcription factor: Evidence that phosphorylation enhances deactivation. EMBO J. 13: 26172624.

Huot, J., G. Roy, H. Lambert, P. Chretien, and J. Landry. 1991. Increased survival after treatments with anticancer agents of Chinese hamster cells expressing the human Mr 27000 heat shock protein. Cancer Res. 51: 5245-5252.

Jaattela, M., D. Wissing, P.A. Bauser, and G.C. Li. 1992. Major heat shock protein hsp70 protects tumor cells from tumor necrosis factor cytotoxicity. EMBO J. 11: 3507-3512.

Jedlicka, P., M.A. Mortin, and C. Wu. 1997. Multiple functions of Drosophila heat shock transcription factor in vivo. $E M B O$ J. 16: 2452-2462.

Jolly, C., R. Morimoto, M. Robert-Nicoud, and C. Vourc'h. 1997. HSF1 transcription factor concentrates in nuclear foci during heat shock: Relationship with transcription sites. I. Cell Sci. 110: 2935-2941.

Jurivich, D.A., L. Sistonen, R.A. Kroes, and R.I. Morimoto. 1992. Effect of sodium salicylate on the human heat shock response. Science 255: 1243-1245.

Kanei-Ishii, C., J. Tanikawa, A. Nakai, R.I. Morimoto, and S. Ishii. 1997. Activation of heat shock transcription factor 3 by c-Myb in the absence of cellular stress. Science 277: 246248.

Kline, M.P. and R.I. Morimoto. 1997. Repression of the heat shock factor 1 transcriptional activation domain is modulated by constitutive phosphorylation. Mol. Cell. Biol. 17: 2107-2115.

Knauf, U., E.M. Newton, J. Kyriakis, and R.E. Kingston. 1996. Repression of human heat shock factor 1 activity at control temperature by phosphorylation. Genes \& Dev. 10: 27822793.

Kroeger, P.E. and R.I. Morimoto. 1994. Selection of new HSF1 and HSF2 DNA-binding sites reveals difference in trimer cooperativity. Mol. Cell. Biol. 14: 7592-7603.

Larson, J.S., T.J. Schuetz, and R.E. Kingston. 1988. Activation in vitro of sequence-specific DNA binding by a human regulatory factor. Nature 335: 372-375.

- 1995. In vitro activation of purified human heat shock factor by heat. Biochemistry 34: 1902-1911.

Lee, B.S., J. Chen, C. Angelidis, D.A. Jurivich, and R.I. Morimoto. 1995. Pharmacological modulation of heat shock factor 1 by antiinflammatory drugs results in protection against stress-induced cellular damage. Proc. Natl. Acad. Sci. 92: 7207-7211.

Leppa, S., L. Pirkkala, S.C. Chow, J.E. Eriksson, and L. Sistonen. 1997. Thioredoxin is transcriptionally induced upon activation of heat shock factor 2. J. Biol. Chem. 272: 30400-30404.

Lis, J. and C. Wu. 1993. Protein traffic on the heat shock promoter: Parking, stalling, and trucking along. Cell 74: 1-4.

Liu, X.D., P.C. Liu, N. Santoro, and D.J. Thiele. 1997. Conservation of a stress response: human heat shock transcription factors functionally substitute for yeast HSF. EMBO $T$. 16: 6466-6477.

Marber, M.S., R. Mestril, S.H. Chi, M.R. Sayen, D.M. Yellon, and W.H. Dillmann. 1995. Overexpression of the rat inducible $70-\mathrm{kD}$ heat stress protein in a transgenic mouse increases the resistance of the heart to ischemic injury. J. Clin. Invest. 95: 1446-1456.

Mason, P.B., Jr. and J.T. Lis. 1997. Cooperative and competitive protein interactions at the hsp70 promoter. J. Biol. Chem. 272: 33227-33233. 
Mathew, A. and R.I. Morimoto. 1998. Role of the heat-shock response in the life and death of proteins. Ann. N.Y. Acad. Sci. 851: 99-111.

Mathew, A., S.K. Mathur, and R.I. Morimoto. 1998. Heat shock response and protein degradation: regulation of HSF2 by the ubiquitin-proteasome pathway. Mol. Cell. Biol. 18: 50915098.

McMillan, D.R., X. Xiao, L. Shao, K. Graves, and I.J. Benjamin. 1998. Targeted disruption of heat shock transcription factor 1 abolishes thermotolerance and protection against heat-inducible apoptosis. J. Biol. Chem. 273: 7523-7528.

Mehlen, P., X. Preville, P. Chareyron, J. Briolay, R. Klemenz, and P. Arrigo. 1995. Constitutive expression of human hsp27, Drosophilia hsp27, or human $\alpha$ B-crystallin confers resistance to TNF- and oxidative stress-induced cytotoxicity in stably transfected murine L929 fibroblasts. J. Immunol. 154: 363-374.

Mestril, R., S.H. Chi, M.R. Sayen, K. O'Reilly, and W.H. Dillmann. 1994. Expression of inducible stress protein 70 in rat heart myogenic cells confers protection against simulated ischemia-induced injury. J. Clin. Invest. 93: 759-767.

Mezger, V., M. Rallu, R.I. Morimoto, M. Morange, and J.P. Renard. 1994. Heat shock factor 2-like activity in mouse blastocysts. Dev. Biol. 166: 819-822.

Mizzen, L.A. and W.J. Welch. 1988. Characterization of the thermotolerant cell. I. Effects on protein synthesis activity and the regulation of heat-shock protein 70 expression. $J$. Cell. Biol. 106: 1105-1116.

Morimoto, R.I. 1993. Cells in stress: transcriptional activation of heat shock genes. Science 259: 1409-1410.

Morimoto, R.I. and M.G. Santoro. 1998. Stress-inducible responses and heat shock proteins: new pharmacologic targets for cytoprotection. Nature Biotech. 16: 833-838.

Morimoto, R.I., A. Tissieres, and C. Georgopoulos. 1990. The stress response, function of the proteins, and perspectives. In Stress proteins in biology and medicine (ed. R.I. Morimoto, A. Tissieres, and C. Georgopoulos), pp. 1-36. Cold Spring Harbor Laboratory Press, Cold Spring Harbor, NY.

- 1994a. Progress and perspectives on the biology of heat shock proteins and molecular chaperones. In The biology of heat shock proteins and molecular chaperones, (ed. R.I. Morimoto, A. Tissieres, and C. Georgopoulos), pp. 1-30. Cold Spring Harbor Laboratory Press, Cold Spring Harbor, NY.

Morimoto, R.I., D.A. Jurivich, P.E. Kroger, S.K. Mathur, S.P. Murphy, A. Nakai, A.K. Sarge, K. Abravaya, and L.T. Sistonen. 1994b. Regulation of heat shock gene transcription by a family of heat shock factors. In The biology of heat shock proteins and molecular chaperones. (ed. R.I. Morimoto, A. Tissieres, and C. Georgopoulos), pp. 417-455. Cold Spring Harbor Laboratory Press, Cold Spring Harbor, NY.

Morimoto, R.I., P.E. Kroeger, and J.J. Cotto. 1996. The transcriptional regulation of heat shock genes: a plethora of heat shock factors and regulatory conditions. In Stress-inducible cellular responses (ed. U. Feige, R. Morimoto, I. Yahara, and B.S. Polla), pp. 139-163. Birkhauser, Boston, MA.

Mosser, D.D., P.T. Kotzbauer, K.D. Sarge, and R.I. Morimoto. 1990. In vitro activation of heat shock transcription factor DNA-binding by calcium and biochemical conditions that affect protein conformation. Proc. Natl. Acad. Sci. 87: 37483752.

Mosser, D.D., J. Duchaine, and B. Massie. 1993. The DNA-binding activity of the human heat shock transcription factor is regulated in vivo by hsp70. Mol. Cell. Biol. 13: 5427-5438.

Mosser, D.D., A.W. Caron, L. Bourget, C. Denis-Larose, and B. Massie. 1997. Role of the human heat shock protein Hsp70 in protection against stress-induced apoptosis. Mol. Cell.
Biol. 17: 5317-5327.

Nakai, A. and R.I. Morimoto. 1993. Characterization of a novel chicken heat shock transcription factor, heat shock factor 3 , suggests a new regulatory pathway. Mol. Cell. Biol. 13: 1983-1997.

Nakai, A., Y. Kawazoe, M. Tanabe, K. Nagata, and R.I. Morimoto. 1995. The DNA-binding properties of two heat shock factors, HSF1 and HSF3, are induced in the avian erythroblast cell line HD6. Mol. Cell. Biol. 15: 5268-5278.

Nakai, A., M. Tanabe, Y. Kawazoe, J. Inazawa, R.I. Morimoto, and K. Nagata. 1997. HSF4, a new member of the human heat shock factor family which lacks properties of a transcriptional activator. Mol. Cell. Biol. 17: 469-481.

Nieto-Sotelo, J., G. Wiederrecht, A. Okuda, and C.S. Parker. 1990. The yeast heat shock transcription factor contains a transcriptional activation domain whose activity is repressed under nonshock conditions. Cell 62: 807-817.

Nover, L., K.-D. Scharf, D. Gagliard, P. Vergne, E. CzarneckaVerner, and W.B. Gurley. 1996. The hsf world: classification and properties of plant heat stress transcription factors. Cell Stress Chaperones 1: 215-223.

Parsell, D.A. and S. Lindquist. 1994. Heat shock proteins and stress tolerence. In The biology of heat shock proteins and molecular chaperones (ed. R.I. Morimoto, A. Tissieres, and C. Georgopoulos), pp. 457-494. Cold Spring Harbor Laboratory Press, Cold Spring Harbor, NY.

Peteranderl, R. and H.C. Nelson. 1992. Trimerization of the heat shock transcription factor by a triple-stranded alphahelical coiled-coil. Biochemistry 31: 12272-12276.

Plumier, J.C., B.M. Ross, R.W. Currie, C.E. Angelidis, H. Kazlaris, G. Kollias, and G.N. Pagoulatos. 1995. Transgenic mice expressing the human heat shock protein 70 have improved post-ischemic myocardial recovery. I. Clin. Invest. 95: 1854-1860.

Rabindran, S.K., G. Giorgi, J. Clos, and C. Wu. 1991. Molecular cloning and expression of a human heat shock factor, HSF1. Proc. Natl. Acad. Sci. 88: 6906-6910.

Rabindran, S.K., R.I. Haroun, J. Clos, J. Wisniewski, and C. Wu. 1993. Regulation of heat shock factor trimer formation: role of a conserved leucine zipper. Science 259: 230-234.

Rabindran, S.K., J. Wisniewski, L. Li, G.C. Li, and C. Wu. 1994. Interaction between heat shock factor and hsp70 is insufficient to suppress induction of DNA-binding activity in vivo. Mol. Cell. Biol. 14: 6552-6560.

Rallu, M., M. Loones, Y. Lallemand, R. Morimoto, M. Morange, and V. Mezger. 1997. Function and regulation of heat shock factor 2 during mouse embryogenesis. Proc. Natl. Acad. Sci. 94: 2392-2397.

Rougvie, A.E. and J.T. Lis. 1988. The RNA polymerase II molecule at the $5^{\prime}$ end of the uninduced hsp70 gene of D. melanogaster is transcriptionally engaged. Cell 54: 795-804.

Sarge, K.D., V. Zimarino, K. Holm, C. Wu, and R.I. Morimoto. 1991. Cloning and characterization of two mouse heat shock factors with distinct inducible and constitutive DNA-binding ability. Genes \& Dev. 5: 1902-1911.

Sarge, K.D., S.P. Murphy, and R.I. Morimoto. 1993. Activation of heat shock gene transcription by heat shock factor 1 involves oligomerization, acquisition of DNA-binding activity, and nuclear localization and can occur in the absence of stress. Mol. Cell. Biol. 13: 1392-1407.

Sarge, K.D., O.K. Park-Sarge, J.D. Kirby, K.E. Mayo, and R.I. Morimoto. 1994. Expression of heat shock factor 2 in mouse testis: Potential role as a regulator of heat-shock protein gene expression during spermatogenesis. Biol. Reprod. 50: 1334 1343.

Satyal, S.H., D. Chen, S.G. Fox, J.M. Kramer, and R.I. Morimoto. 
1998. Negative regulation of the heat shock transcriptional response by HSBP1. Genes \& Dev. 12: 1962-1974.

Scharf, K.D., S. Rose, W. Zott, L. Nover, and F. Schoffl. 1990. Three tomato genes code for heat stress transcription factors with a region of remarkable homology to the DNA-binding domain of the yeast HSF. EMBO I. 9: 4495-4501.

Scharf, K.D., S. Rose, J. Thierfelder, and L. Nover. 1993. Two cDNAs for tomato heat stress transcription factors. Plant Physiol. 102: 1355-1356.

Schuetz, T.J., G.J. Gallo, L. Sheldon, P. Tempst, and R.E. Kingston. 1991. Isolation of a cDNA for HSF2: evidence for two heat shock factor genes in humans. Proc. Natl. Acad. Sci. 88: 6911-6915.

Schultheiss, J., O. Kunert, U. Gase, K.D. Scharf, L. Nover, and H. Rüterjans. 1996. Solution structure of the DNA-binding domain of the tomato heat stress transcription factor HSF24. Eur. J. Biochem. 236: 911-921.

Shi, Y., P.E. Kroeger, and R.I. Morimoto. 1995. The carboxylterminal transactivation domain of heat shock factor 1 is negatively regulated and stress responsive. Mol. Cell. Biol. 15: 4309-4318.

Shi, Y., D.D. Mosser, and R.I. Morimoto. 1998. Molecular chaperones as HSF1-specific transcriptional repressors. Genes \& Dev. 12: 654-666.

Sistonen, L., K.D. Sarge, B. Phillips, K. Abravaya, and R.I. Morimoto. 1992. Activation of heat shock factor 2 during hemin-induced differentiation of human erythroleukemia cells. Mol. Cell. Biol. 12: 4104-4111.

Sistonen, L., K.D. Sarge, and R.I. Morimoto. 1994. Human heat shock factors 1 and 2 are differentially activated and can synergistically induce hsp70 gene transcription. Mol. Cell. Biol. 14: 2087-2099.

Sorger, P.K. 1990. Yeast heat shock factor contains separable transient and sustained response transcriptional activators. Cell 62: 793-805.

Sorger, P.K. and H.C. Nelson. 1989. Trimerization of a yeast transcriptional activator via a coiled-coil motif. Cell 59: 807-813.

Sorger, P.K. and H.R. Pelham. 1988. Yeast heat shock factor is an essential DNA-binding protein that exhibits temperature-dependent phosphorylation. Cell 54: 855-864.

Sorger, P.K., M.J. Lewis, and H.R. Pelham. 1987. Heat shock factor is regulated differently in yeast and HeLa cells. Nature 329: $81-84$

Tanabe, M., Y. Kawazoe, S. Takeda, R.I. Morimoto, K. Nagata, and A. Nakai. 1998. Disruption of the HSF3 gene results in the severe reduction of heat shock gene expression and loss of thermotolerance. EMBO J. 17: 1750-1758.

Tanabe, M., A. Nakai, Y. Kawazoe, and K. Nagata. 1997. Different thresholds in the responses of two heat shock transcription factors, HSF1 and HSF3. J. Biol. Chem. 272: 1538915395.

Theodorakis, N.G., D.J. Zand, P.T. Kotzbauer, G.T. Williams, and R.I. Morimoto. 1989. Hemin-induced transcriptional activation of the HSP70 gene during erythroid maturation in K562 cells is due to a heat shock factor-mediated stress response. Mol. Cell. Biol. 9: 3166-3173.

Treuter, E., L. Nover, K. Ohme, and K.D. Scharf. 1993. Promoter specificity and deletion analysis of three tomato heat stress transcription factors. Mol. \& Gen. Genet. 240: 113-125.

Tsukiyama, T., P.B. Becker, and C. Wu. 1994. ATP-dependent nucleosome disruption at a heat-shock promoter mediated by binding of GAGA transcription factor. Nature 367: 525532.

Voellmy, R. 1994. Transduction of the stress signal and mechanisms of transcriptional regulation of heat shock/stress pro- tein gene expression in higher eukaryotes. Crit. Rev. Eukaryot. Gene. Expr. 4: 357-401.

1996. Sensing stress and responding to stress. In Stressinducible cellular responses (ed. U. Feige, R.I. Morimoto, I. Yahara, and B.S. Polla), pp. 121-137. Birkhauser, Boston, MA.

Vuister, G.W., S.J. Kim, C. Wu, and A. Bax. 1994. NMR evidence for similarities between the DNA-binding regions of Drosophila melanogaster heat shock factor and the helix-turnhelix and HNF-3/forkhead families of transcription factors. Biochemistry 33: 10-16.

Westwood, J.T. and C. Wu. 1993. Activation of Drosophila heat shock factor: conformational change associated with a monomer-to-trimer transition. Mol. Cell. Biol. 13: 34813486.

Wiederrecht, G., D. Seto, and C.S. Parker. 1988. Isolation of the gene encoding the $S$. cerevisiae heat shock transcription factor. Cell 54: 841-853.

Wisniewski, J., A. Orosz, R. Allada, and C. Wu. 1996. The Cterminal region of Drosophila heat shock factor (HSF) contains a constitutively functional transactivation domain. Nucleic Acids Res. 24: 367-374.

Wu, C. 1980. The $5^{\prime}$ ends of Drosophila heat shock genes in chromatin are hypersensitive to DNase I. Nature 286: 854 860.

1984. Two protein-binding sites in chromatin implicated in the activation of heat-shock genes. Nature 309: 229-234.

1995. Heat shock transcription factors: structure and regulation. Annu. Rev. Cell Dev. Biol. 11: 441-469.

Wu, C., J. Clos, G. Giorgi, R.I. Haroun, S.-J. Kim, S.K. Rabindran, J.T. Westwood, J. Wisniewski, and G. Yim. 1994. Structure and regulation of heat shock transcription factor. In The biology of heat shock proteins and molecular chaperones (ed. R.I. Morimoto, A. Tissieres, and C. Georgopoulos), pp. 395-416. Cold Spring Harbor Laboratory Press, Cold Spring Harbor, NY.

Zhong, M., A. Orosz, and C. Wu. 1998. Direct sensing of heat and oxidation by Drosophila heat shock transcription factor. Mol. Cell 2: 101-108.

Zuo, J., R. Baler, G. Dahl, and R. Voellmy. 1994. Activation of the DNA-binding ability of human heat shock transcription factor 1 may involve the transition from an intramolecular to an intermolecular triple-stranded coiled-coil structure. Mol. Cell. Biol. 14: 7557-7568.

Zuo, J., D. Rungger, and R. Voellmy. 1995. Multiple layers of regulation of human heat shock transcription factor 1. Mol. Cell. Biol. 15: 4319-4330.

Zou, J., Y. Guo, T. Guettouche, D.F. Smith, and R. Voellmy. 1998. Repression of heat shock transcription factor HSF1 activation by HSP90 (HSP90 complex) that forms a stresssensitive complex with HSF1. Cell 94: 471-480. 


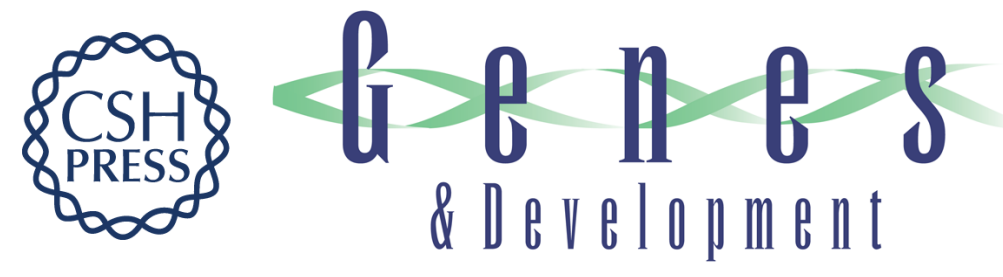

\section{Regulation of the heat shock transcriptional response: cross talk between a family of heat shock factors, molecular chaperones, and negative regulators}

Richard I. Morimoto

Genes Dev. 1998, 12:

Access the most recent version at doi:10.1101/gad.12.24.3788

References This article cites 95 articles, 58 of which can be accessed free at:

http://genesdev.cshlp.org/content/12/24/3788.full.html\#ref-list-1

License

Email Alerting Receive free email alerts when new articles cite this article - sign up in the box at the top

Service right corner of the article or click here.

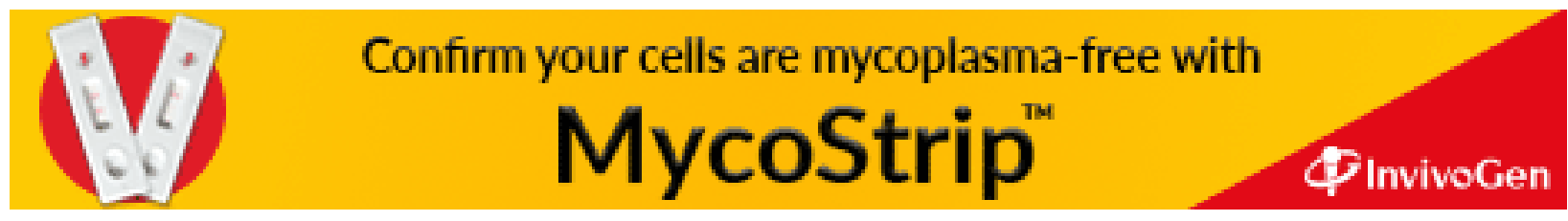

